\title{
IMPACT OF GDP, FOREIGN DIRECT INVESTMENT, INFLATION RATE, AND INTERST RATE ON STOCK MARKET VALUES IN SAUDI ARABIA
}

\author{
Abdullah Algarini \\ Collage of Economics and Administrative Sciences, Al Imam Mohammad Ibn Saud \\ Islamic University, PO box 395306, Riyadh 11375, Saudi Arabia \\ DOI: 10.46609/IJSSER.2020.v05i07.002 URL: https://doi.org/10.46609/IJSSER.2020.v05i07.002
}

\begin{abstract}
This study aims to find the long run and short run equilibrium relationships between stock market values (MV) and macroeconomic variables (GDP, foreign direct investment (FDI), inflation rate (INF), and interest rate (IR)) using annual time series data for the 1993-2018 period. The results indicate that all macroeconomic variables are stationary in the first difference and co-integrated with MV. The results also indicate that there is a long run relationship between MV and all macroeconomic variables and between GDP and all other variables. But there is one short run relationship between stock market values and all variables in lagged. The results of this study suggest that Saudi Arabian policy makers should pay attention to the effects of monetary policies and economic activity measurement on the stock market index.
\end{abstract}

Keywords: GDP, FDI, inflation rate, interest rate, stock market, and Saudi Arabia

JEL CODE: C32, G1, E43, H54, P24

\section{INTRODUCTION}

The stock market index is a general expression used to describe an organized exchange where shares of companies are traded. The movement of the stock market index depends on the rational as well as the irrational behavior of the investor. The rational behavior that can affect stock market values relies on some factors that we can evaluate. The factors that impact the price behavior influence not only stock market values, but also other economic elements which can be further divided into microeconomic and macroeconomic controls. King (1966) shows that the 


\section{International Journal of Social Science and Economic Research}

ISSN: $2455-8834$

Volume: 05, Issue: 07 "July 2020"

stock market is influenced by macroeconomic factors by an average of $50 \%$. Thus, we will focus in this study on the macroeconomic factors which affect the stock market.

This paper focuses on macroeconomic factors like gross domestic product (GDP), inflation rate (INF), foreign direct investment (FDI), and interest rate (IR). These macroeconomic factors would affect the returns reflected in the stock market index. FDI inflows have affected on the economy of Saudi Arabia both directly and indirectly by playing an important role in providing stability to and motivating growth potentials for the economy (Algarini, 2018, Bardesi, 2016).

Saudi Arabia recently started improving the investment environment to increase their share of FDI flows. The government plan included easing restrictions on FDI, privatization of stateowned enterprises, domestic financial reforms, and tax incentives and subsidies (World Bank, 2019). For example, as regards foreign direct investment, net inflows (\% of GDP) went up from 0.04\% in 1996 to 2.9\% in 2018 (International Monetary Fund, 2019).

Gross Domestic Production (GDP) also has a relationship with the stock market. As the GDP growth rises and falls, so does activity in the stock market. The fall of GDP growth generally occurs because of a fall in investment expenditure and which is typically followed by a fall in stock market prices.

Changes in the Inflation Rate cause increased stock market volatility and risk during different time periods. The expectation of a high inflation rate leads investors to keep less cash because of over time the money loses value. Variations in the inflation rate constituter a major problem for analyzing stock market returns over a long run. For example, most developing countries suffer declines in their stock market because of high inflation (Geetha et al, 2011). For example, the interest rate into Saudi Arabia went down by over 2 percentage points (from $1.22 \%$ in 1996 to$1.12 \%$ in 2001), while stock market capitalization (\%GDP) increased from $27.64 \%$ to $38.26 \%$ during the same period (World Bank, 2019).

The impact of interest rate changes is not immediate on the stock market. Investors should take into consideration that the effect on the economy takes about 12 months to see a widespread impact. Because of a high interest rate, credit becomes more expensive, which causes negative effects on profits of companies and stock prices ${ }^{1}$. A fall in interest rates increases the supply of money that affects economic activities in any economy. For example, expansion of the money supply in an economy can be used so that it is distributed to investments that can influence the behavior and development of stock market prices. According to the World Bank (2019), FDI net

${ }^{1}$ https://www.investopedia.com/investing/how-interest-rates-affect-stock-market/ 


\section{International Journal of Social Science and Economic Research}

ISSN: $2455-8834$

Volume: 05, Issue: 07 "July 2020"

inflows (\%GDP) into Saudi Arabia went down from $0.40 \%$ in 1996 to $0.27 \%$ in 2001, while stock market capitalization (\%GDP) increased from $27.64 \%$ to $38.26 \%$ during the same period.

This study will be undertaken to investigate the impact of GDP, inflation rate, interest rate, and foreign direct investment (DFI) on Saudi Market Value of shares (MV) as a proxy of the Saudi market in order to reveal the nature and strength of relationships between these variables in the long and short run. The rest of the paper is organized as follows. Section 2 shows the literature review. Section 3 explains the data and econometric methodology. Section 4 analyses the empirical result and discussion and section 5 explains the conclusion of the paper.

\section{LITERATURE}

Adam and Tweneboah (2008) examine the effect of Foreign Direct Investment (FDI) on the stock market development in Ghana. This paper reveals that an increase in FDI significantly affects the development of their stock market. Geetha et al (2011) study the relationship between stock market returns and inflation rate. This study finds that there is long run relationship between expected and unexpected inflation with stock market returns. This result shows that there is no short run relationship between inflation rate and stock market returns for Malaysia and the USA, but it does exists for China.

Tursoy and Faisal (2016) study the interrelationship between stock prices and GDP in Turkey during 1992-2014. They find strong evidence that both stock prices and GDP are strongly cointegrated in the long run and that this relationship is significantly positive. In the short run, they find a unidirectional causality from GDP on stock prices. Karunanayake, Valadkhani, and O'Brien (2012) examine the relationship between stock market and GDP growth in four AngloSaxon economies in three countries: USA, Canada, and Australia. They find that GDP growth causes increase stock market returns only in the USA economy, while, in contrast, they find that increase stock market returns cause GDP growth in both the USA and Australia. Mauro (2003) studies the correlation between output growth and lagged stock market returns in a panel of emerging market economies and advanced economies. Al-Sharkas (2004) finds a relationship between stock market performance in Jordan and a GDP deflator in the long run. This study shows that any positive change in trading value leads to an increase in the GDP deflator. Ake(2010) investigates the relationship between market capitalization, total trade value, turnover ratio and GDP growth in 5 Euronext countries. He shows that there a positive link between stock market returns and economic growth for some countries that have liquid and highly active stock markets and the relationship is rejected for countries in which their stock market is small and less liquid. Van Nieuwerburgh, Buelens, and Cuyvers (2006) find strong evidence that stock market development caused GDP growth in Belgium during the period from 1873-1935. They also 


\section{International Journal of Social Science and Economic Research}

ISSN: $2455-8834$

Volume: 05, Issue: 07 "July 2020"

mention that institutional change increases the relationship between stock market development and economic growth.

Stock market returns and interest rates are two important factors of GDP growth, and Alam and Uddin (2009) indicate that these two factors are also important controls on economic growth. This study finds evidence supporting the existing relationship between stock market returns and interest rates for fifteen developed and developing countries. For those countries, interest rates have a significant negative relationship with share price. Ali (2014) examines the relationship between stock market returns and interest rates in the Pakistani market. He finds that interest rates have a negative influence on stock market returns in that a higher interest rate leads to decreased efficiency of the stock market. He recommends that the Pakistani government should lower its interest rate to develop the economy.

On the other hand, it is important to know the effect of different macroeconomic variables on stock market returns in different countries. Samontaray, Nugali, and Sasidhar (2014) study the relationship between Saudi Market Value of shares (MV) and some macroeconomic variables. They find that Saudi Exports, PE ratio, and oil price are significantly correlated with TASI at 5\% level. By using step-wise regression analysis, this study reveals that the correlation revealed by multiple regression models is significant at the $1 \%$ level and the variable PE ratio is the most important control on TASI, followed by oil price and Saudi Exports and that these variables explain 93\% of the variation in the TASI. Osamwonyi and Evbayiro-Osagie (2012) determine the relationship between stock market index and GDP, money supply, interest rate, inflation rate, exchange rates, and fiscal deficit in Nigeria during 1975-2005. The results of the study show that all variables positively influenced the stock market index. Reddy (2012) demonstrates that the variation of GDP, interest rate, and inflation rate explain $95 \%$ of the variation in stock market returns. Also, he finds that a reduction in inflation and interest rate leads to increase in stock market prices in India. Matadeen (2019) indicates that GDP growth, banking sector development, stock market liquidity, and gross fixed capital formation drove stock market development in the Mauritius during 1989-2016. Rozeff (1974) examines stock market efficiency with respect to the supply of money. He finds that no meaningful lag exists in the effect of changes in the supply of money on stock market returns and that no profitable safety trading rules using previous values of the money supply exist. Alatiqi and Fazel (2008) use Cointegration and Granger Causality tests and finds that the relationship between supply of money and stock prices is an unstable causal.Sirucek (2012) focuses on the US stock market during the period from 1967-2011. He finds that money supply (M2) affects stock market when applying a delay of up to 6 months, while the effect of money supply (money with zero maturity) on stock market returns happens only with a delay of 6 or more months. 


\section{DATA ANDMETHODOLOGY}

In this paper, time series analysis will be used from 1993-2018 for all variables. The variables are market value of shares (MV), Real Gross Domestic Product (GDP), Inflation Rate (IF), Interest Rate (IR), and Foreign Direct Investment (FDI). The main data sources are the World Bank and International Monetary Fund (IMF).

This paper aims to study the long run and short run relationship between the stock market value index (MV) and important macroeconomics variables in Saudi Arabia. Accuracy in the estimate of the relationship, the presence of stationary and cointegration between time series of variables will be examined. This test allows us to implement the VEC Model, which assumes all variables to be cointegrated among the variables, or to implement the VAR model in case of no cointegration $^{2}$.

\subsection{Stationary Test (Unit Root Test)}

Since macroeconomics variables are mostly non-stationary and because the OLS Model gives false results, reliable analyses require a testing program in which the variables are artificially held stationary to provide stability in the mean and variance through the time series. In this field, Dickey and Fuller (1981) improved a test for unit root. In this test, if the calculated value, in absolute terms, is less than the p-value at $5 \%$, this means that the data are non-stationary.

\subsection{Cointegration Test}

If the time series used in this study becomes stationary at the same level I (1), then it would examine the cointegration among the variables. Johansen and Juselius (1990) provided two likelihood ratio tests to get the number of cointegrated vectors ${ }^{3}$. The results derived from this test are used in applying the VEC model which measures the long and short run relationships.

\subsection{Vector Error Correction (VEC) Model Test}

The VEC Model test is used because the time series are not stationary in their levels but are in their difference and the variables are cointegrated. This study utilizes VEC model to analyze the long run and short run dynamic of influence of changes in GDP, inflation rate, interest rate, and foreign direct investment on stock market values.

\footnotetext{
${ }^{2} \mathrm{H}_{0}$ : there is no cointegration among the variables, $\mathrm{H}_{1}$ : there is cointegration, if we choose $\mathrm{H}_{0}$, we can use VAR model and when we choose $\mathrm{H}_{1}$, we can use VECmodel.

3The null hypothesis of the first test (Trace), $\mathrm{H}_{0}$ : there is no cointegration among the variables; $\mathrm{H}_{1}$ : there is cointegration among the variables.
} 


\section{EMPIRICALRESULTS}

\subsection{Result of ADF test}

Table 1 represents the result of ADF test. All the five variables (MV, GDP, FDI, INF, and IR) are non-stationary at the level data. However, these variables become stationary at the first difference after the inclusion of intercept, intercept and trend, and without trend and intercept. The results of Phillips-Perron (PP) in table 2 show also that all variables are non-stationary in the level. However, the results in the first difference become stationary after the inclusion intercept, intercept and trend, and without trend and intercept. The results are consistent with ADF test results. Thus, stock market value index and other macroeconomic variables are integrated of thesame I (1) order. Since, the variables are stationary in same level, we can use the VAR, or VECM models to study the relationships between the variables.

\section{Table 1: ADF tests result}

\begin{tabular}{|l|l|l|l|l|l|l|}
\hline Variable & \multicolumn{2}{|l|}{ Intercept } & \multicolumn{2}{l|}{ Trend and intercept } & \multicolumn{2}{l|}{ Without Trend and intercept } \\
\cline { 2 - 7 } & Level & $\begin{array}{l}\text { First } \\
\text { Difference }\end{array}$ & Level & $\begin{array}{l}\text { First } \\
\text { Difference }\end{array}$ & Level & First Difference \\
\hline MV & -1.251 & $-3.426^{* *}$ & -2.630 & $-3.344^{* * *}$ & 0.121 & $-3.283^{*}$ \\
\hline GDP & -0.105 & $-3.997^{*}$ & -2.442 & $-3.978^{* *}$ & 1.515 & $-3.327^{*}$ \\
\hline FDI & 1.221 & $-5.435^{*}$ & -0.677 & $-6.130^{*}$ & 1.637 & $-5.220^{*}$ \\
\hline INF & -1.688 & $-4.049^{*}$ & -1.644 & $-3.865^{* *}$ & -1.204 & $-4.140^{*}$ \\
\hline IR & -2.171 & $-3.800^{*}$ & -3.648 & $-3.840^{* *}$ & -1.454 & $-3.755^{*}$ \\
\hline
\end{tabular}

$*$, **, and $* * *$ refer to that the null hypotheses that the time series contains a unit root is rejected at $1 \%, 5 \%$, and $10 \%$ significance level, respectively. The lags of all variables in level and first difference are lag $(2,1)$ for MV, $\operatorname{lag}(1,0)$ for GDP, lag $(2,1)$ for FDI, lag $(1,1)$ for INF, and lag $(2,4)$ for IR.

Table 2: Philips-Perron tests results.

\begin{tabular}{|l|l|l|l|l|l|l|}
\hline Variable & \multicolumn{2}{|l}{ Intercept } & \multicolumn{2}{l|}{ Trend and intercept } & \multicolumn{2}{l|}{$\begin{array}{l}\text { Without Trend and } \\
\text { intercept }\end{array}$} \\
\cline { 2 - 7 } & Level & $\begin{array}{l}\text { First } \\
\text { Difference }\end{array}$ & Level & $\begin{array}{l}\text { First } \\
\text { Difference }\end{array}$ & Level & First Difference \\
\hline MV & $-4.232^{*}$ & $-36.288^{*}$ & $-18.503^{* *}$ & $-36.284^{*}$ & $-0.084^{*}$ & $-35.840^{*}$ \\
\hline GDP & 0.032 & $-21.131^{*}$ & $-8.010^{*}$ & $-21.452^{* *}$ & $1.263^{*}$ & $-16.868^{*}$ \\
\hline FDI & 6.833 & $-40.890^{*}$ & $-5.124^{*}$ & -40.446 & 4.358 & $-39.901^{*}$ \\
\hline INF & $-8.587^{*}$ & $-32.438^{*}$ & $-9.788^{*}$ & $-32.753^{*}$ & $-4.810^{*}$ & $-32.439^{*}$ \\
\hline IR & $-4.921^{*}$ & $-13.819^{* *}$ & $-11.046^{*}$ & -13.545 & $-1.506^{*}$ & $-13.863^{*}$ \\
\hline
\end{tabular}


$*$, **, and *** refer to that the null hypotheses that the time series contains a unit root is rejected at $1 \%, 5 \%$, and $10 \%$ significance level, respectively. The lags of all variables in level and first difference are lag $(2,1)$ for MV, $\operatorname{lag}(1,0)$ for GDP, lag $(2,1)$ for FDI, lag $(1,1)$ for INF, and lag $(2,4)$ for IR.

\subsection{Result of Johannes's Cointegration}

Table 3 shows the results of Maximal Eigen statistic and Trace statistic tests. It represents the Johansen cointegration tests to explore the relationship among in the long run. The result of both trace and maximum-eigenvalue tests suggest that there is at least one cointegration vector exists between market value index and other variables. The result emphasizes that there is a long run relationship among these variables. This leads to the conclusion that long run movements of the variables are determined by one equilibrium relationship.

Table 3: Result of Johansen's Cointegration

\begin{tabular}{|l|l|l|l|l|l|}
\hline $\begin{array}{l}\text { Hypothesis No. of } \\
\text { cointegration vectors }\end{array}$ & $\mathrm{H}_{0}$ & $\begin{array}{l}\text { Trace } \\
\text { statistic }\end{array}$ & $\begin{array}{l}\text { Critical } \\
\text { values at 5\% }\end{array}$ & $\begin{array}{l}\text { Max. Eigen } \\
\text { Values }\end{array}$ & $\begin{array}{l}\text { Critical values } \\
\text { at 5\% }\end{array}$ \\
\hline None & $\mathrm{R}=0$ & 71.1292 & 68.52 & 35.3538 & 33.46 \\
\hline At most one & $\mathrm{R} \leq 1$ & $35.7754 * *$ & 47.21 & $20.4491 * *$ & 27.07 \\
\hline
\end{tabular}

Note: The trace statistics is the maximum value. ${ }^{* *}$ shows the significance at $5 \%$ level. The lag length was selected by using the Lag criteria. The Autocorrelation LM tests was performed and found no serial correlation problems.

\subsection{Result of Lag Order Selection Criteria}

The second step in multivariate cointegration analysis is the appropriate lag selection for the variables. Table 4 shows four order criteria, Likelihood Ratio (LR), Akaike Information (AIC), Schwarz Bayesian Criteria (SBC), Hannan-Quinn Criteria (HQ). The all criteria indicate that the optimal lag is 4. 
International Journal of Social Science and Economic Research

ISSN: $2455-8834$

Volume: 05, Issue: 07 "July 2020"

Table 4: VECM lag Order Selection Criteria on the length of lags

\begin{tabular}{|l|l|l|l|l|}
\hline Lag & LR & AIC & HQ & SBC \\
\hline $\mathbf{0}$ & 122.23 & 74.9063 & 75.1109 & 76.3903 \\
\hline $\mathbf{1}$ & 117.23 & 71.1716 & 71.5467 & 77.1379 \\
\hline $\mathbf{2}$ & 2000.1 & -37.1686 & -36.623 & 74.6164 \\
\hline $\mathbf{3}$ & 3468.1 & -228.729 & -228.115 & -221.223 \\
\hline $\mathbf{4}$ & $111.07^{*}$ & $-234.899^{*}$ & $-234.285^{*}$ & $-227.107^{*}$ \\
\hline $\mathbf{5}$ & -37.083 & -232.839 & -232.225 & -225.107 \\
\hline
\end{tabular}

\subsection{Result of Long and Short-Run Relationships}

Using Vector Error Correction (VEC) model, table 5 presents the long and short run relationships between dependent variables and independent variables. As the estimations in the table 5 reveal, the lagged error correction term (ECT) is statistically significant with the anticipated negative sign. The coefficient of ECT $(-0.06)$ indicates that there is a long run causality running from all variables to market value index. In addition, there is another long run Granger causality, which runs interactively through the ECT from all variables to GDP by -0.1 . This result confirms that there is a bidirectional long run relationship between stock market value (MV) and GDP and that the speed of adjustment to equilibrium is relatively high in both relationships. The results of ECT $(6 \%, 10 \%)$ in first and second column of table 5 suggests that $60 \%$ and $100 \%$ of the disequilibrium from the previous year is converged and corrected quickly, back to the long run equilibrium in the current year. On the other hand, this study shows in the first column from table 5 that there is a significant short run relationship running from GDP, FDI, INF, and IR to a lagged response in stock market values (MV). This result confirms that the market value (MV) reacts to GDP, foreign direct investment (FDI), interest rate (IR), and inflation rate (INF). However, in the second column, there is no a significant short run relationship running from MV, FDI, INF, and IR to a lagged response in GDP. Therefore, GDP does not react to MV, FDI, INF, and IR in the short run. That means there is a short run unidirectional Granger causality, which implies that GDP and another variable contributes to development of stock market index. Therefore, the stock market value develops as the economy of Saudi Arabia develops in the short run. Finally, this result confirms that the fiscal policy and monetary policy are clear for investors in Saudi Arabia in the short run and long run.

Table 6 shows the first normalized equation that can be constructed. This equation indicates that GDP, inflation rate, foreign direct investment, and interest rate have a positive impact on the 


\section{International Journal of Social Science and Economic Research}

ISSN: $2455-8834$

Volume: 05, Issue: 07 "July 2020"

stock market value index. The findings suggest that GDP and FDI are the most important variables influencing the stock market index. The attraction of FDI into Saudi Arabia creates jobs and employment in the economy and improves production, financial sector health, and improvement in management techniques, and moreover, increases the values of the stock market. In this study, change in inflation rate leads to a positive change in stock market value because the price of products rises faster than wage rates in Saudi Arabia. In summary, the result of a moderate interest rate increases seems to be that it encourages investment and transactions in the stock market value in Saudi Arabia.

Table 5: Vector Error Correction Estimates in short and long run

\begin{tabular}{|c|c|c|c|c|c|}
\hline & $\Delta M V$ & $\triangle G D P$ & $\Delta F D I$ & $\Delta I N F$ & $\Delta I R$ \\
\hline ECT & $-0.65994 *$ & $-0.9873 * *$ & -0.000214 & -0.002265 & 0.001229 \\
\hline$\Delta M V(-1)$ & $-2.927083^{*}$ & $-4.5332 * *$ & -0.001387 & -0.008239 & 0.005547 \\
\hline$\Delta M V(-2)$ & -1.101849 & $-3.51232 * *$ & -0.001286 & -0.005463 & 0.004473 \\
\hline$\Delta M V(-3)$ & 0.253144 & $1.30564 * *$ & 0.000125 & $0.00483 * *$ & -0.001019 \\
\hline$\triangle G D P(-1)$ & $1217.695^{*}$ & $2.47310^{*}$ & 0.00361 & 0.05123 & -0.00235 \\
\hline$\Delta G D P(-2)$ & -2.3123 & -.7003858 & -0.000276 & -0.0235 & 0.004451 \\
\hline$\Delta G D P(-3)$ & 3.7632 & 0.931834 & 0.000678 & 0.0213 & -0.01042 \\
\hline$\Delta F D I(-1)$ & $7654.44^{*}$ & 1.06231 & 1.332101 & 22.00554 & -11.27399 \\
\hline$\Delta F D I(-2)$ & $8380.071^{*}$ & $1.55342 * *$ & 3.885541 & 32.41768 & -17.52408 \\
\hline$\Delta F D I(-3)$ & 2244.244 & $6.142365^{* *}$ & 1.86004 & 12.65824 & -6.990424 \\
\hline$\Delta I N F(-1)$ & $-158.0756 * * *$ & 3.97232 & 0.088237 & -0.0445842 & -0.21644 \\
\hline$\Delta I N F(-2)$ & $-129.6951 * * *$ & $-4.24342 * *$ & -0.15107 & -0.8931632 & 0.56235 \\
\hline$\Delta I N F(-3)$ & $118.1153 * *$ & $1.99432 * *$ & 0.02825 & $0.67210^{* * *}$ & -0.27408 \\
\hline$\Delta I R(-1)$ & $1193.861 *$ & $1.79323 * *$ & 0.360512 & 3.381404 & -1.688648 \\
\hline$\Delta I R(-2)$ & $1368.108^{* *}$ & $2.17326^{* * * *}$ & 0.404921 & 3.868165 & -2.501381 \\
\hline$\Delta I R(-3)$ & $893.1881 * *$ & $1.923765^{* *}$ & 0.621028 & 5.020438 & -2.732113 \\
\hline
\end{tabular}

The symbol $(*, * *, * * *)$ shows the coefficient significantly at $1 \%, 5 \%$, and $10 \%$ at level. 
International Journal of Social Science and Economic Research

ISSN: $2455-8834$

Volume: 05, Issue: 07 "July 2020"

Table 6: Johansen normalization restrictions

\begin{tabular}{|l|l|l|l|l|}
\hline MV & GDP & FDI & INF & IR \\
\hline $\mathbf{1}$ & 191.1946 & 13006.79 & 612.0469 & 2039.631 \\
\hline S.E & 84.06123 & 1729.386 & 67.94714 & 275.1275 \\
\hline Z-Value & 2.27 & 7.52 & 9.01 & 7.41 \\
\hline
\end{tabular}

\section{CONCLUSION}

The paper aims to investigate the dynamic relationship between stock market value and GDP, FDI, inflation rate, and interest rate for Saudi Arabia using the yearly data from 1993-2018. The empirical method implicit in the Johansen and Juselius testing approach to cointegration suggests that VEC model should be used to examine the existence of a long run and short run equilibrium relationships between stock market value and the remaining variables. The results provide strong evidence that both stock market value and GDP, as wee as foreign direct investment, inflation rate, and interest rate, are strongly cointegrated and have a short run and long run relationship. The estimation of the VEC model suggests that there is a positive and significantly dynamic relationship between the stock market value index and GDP and remaining variables. This means that if the GDP, FDI, inflation rate, and interest rate increase (decrease) the stock market value of Saudi Arabia will rise (fall), which is also confirmed by Evbayiro-Osagie (2012), Reddy (2012), and Matadeen (2019) in their studies. If the elasticity of the GDP rises by 1\%, then the stock market will also rise by $0.19 \%$. The coefficient of the error correction term $(-0.65)$ is smaller than the unity in the absolute term and negative, representative of the presence of a long run relationship among the variables in the VEC model. This implies that the level of stock market value is above or below the equilibrium level; it adjusts by $65 \%$ per year.

The Granger causality test result test shows a long run as well as joint (long and short run) bidirectional causality between GDP and stock market value. That suggests the importance of the relationship between GDP and stock market that in helping to predict and accurately forecast trends to protect the economy from challenging crises in the future. A short run unidirectional causality running from GDP, FDI, INF, and IR to stock market value indicates that the change in macroeconomic variables are a good indicator for predicting stock market returns in the short run. This paper recommends the policy makers to use stock market information and past values of GDP, FDI, and monetary policy by making accurate forecasts about possible crises and formulating efficient strategies to protect the stock market from fluctuations.

\section{REFERENCES}




\section{International Journal of Social Science and Economic Research}

ISSN: $2455-8834$

Volume: 05, Issue: 07 "July 2020"

Adam, A. M., \& Tweneboah, G. (2008). Foreign direct investment (FDI) and stock market development: Ghana evidence.

Ake, B. (2010). The role of stock market development in economic growth: evidence from some Euronext countries. International Journal of Financial Research, 1(1), 14-20.

Alam, M. D., \&Uddin, G. (2009). Relationship between interest rate and stock price: empirical evidence from developed and developing countries. International Journal of Business and Management (ISSN 1833-3850), 4(3), 43-51.

Alatiqi, S., \& Fazel, S. (2008). Can money supply predict stock prices? Journal for economic educators, 8(2), 54-59.

Algarini, A. (2018), The Contribution of Local and Foreign Labor to Total Factor Productivity in Saudi Arabia, Journal of Economics and Sustainable Development, Vol 9, No 6

Ali, H. (2014). Impact of Interest Rate on Stock Market; Evidence from Pakistani Market. Journal of Business and Management, 16(1), 64-6.

Al-Sharkas, A. (2004). The dynamic relationship between macroeconomic factors and the Jordanian stock market. International Journal of Applied Econometrics and Quantitative Studies, 1(1), 97-114.

Bardesi, H. J. (2016). The Impact Of Fdi On Growth Of Saudi Economy: An Empirical Evaluation Of Manufacturing Sector. Eurasian Journal of Economics and Finance, 4(3), $1-13$.

Dickey, D. A., \& Fuller, W. A. (1981). Likelihood ratio statistics for autoregressive time series with a unit root. Econometrica: journal of the Econometric Society, 1057-1072.

Geetha, C., Mohidin, R., Chandran, V. V., \& Chong, V. (2011). The relationship between inflation and stock market: Evidence from Malaysia, United States and China. International journal of economics and management sciences, 1(2), 1-16.

International Monetary Fund, 2019

Johansen, S., \& Juselius, K. (1990). Maximum likelihood estimation and inference on cointegration - with applications to the demand for money. Oxford Bulletin of Economics and statistics, 52(2), 169-210. 
Karunanayake, I., Valadkhani, A., \& O'Brien, M. (2012). Stock market and GDP growth volatility spillovers.

King, B. F. (1966). Market and industry factors in stock price behavior. the Journal of Business, 39(1), 139-190.

Matadeen, J. (2019). Stock Market Development: An Assessment of its Macroeconomic and Institutional Determinants in Mauritius. International Journal of Economics and Financial Issues, 9(4), 197.

Mauro, P. (2003). Stock returns and output growth in emerging and advanced economies. Journal of Development Economics, 71(1), 129-153.

Osamwonyi, I. O., \& Evbayiro-Osagie, E. I. (2012). The relationship between macroeconomic variables and stock market index in Nigeria. Journal of Economics, 3(1), 55-63.

Reddy, D. L. (2012). Impact of inflation and GDP on stock market returns in India. International Journal of Advanced Research in Management and Social Sciences, 1(6), 120-136.

Reddy, D. L. (2012). Impact of inflation and GDP on stock market returns in India. International Journal of Advanced Research in Management and Social Sciences, 1(6), 120-136.

Rozeff, M. S. (1974). Money and stock prices: Market efficiency and the lag in effect of monetary policy. Journal of financial Economics, 1(3), 245-302.

Samontaray, D. P., Nugali, S., \& Sasidhar, B. (2014). A study of the effect of macroeconomic variables on stock market: Saudi Perspective. International Journal of Financial Research, 5(4), 120-127.

Sirucek, M. (2012). The impact of money supply on stock prices and stock bubbles.

Tursoy, T., \& Faisal, F. (2016). Causality between stock price and GDP in Turkey: an ARDL bounds testing approach. Romanian Statistical Review, 64(4), 3-19.

Van Nieuwerburgh, S., Buelens, F., \&Cuyvers, L. (2006). Stock market development and economic growth in Belgium. Explorations in Economic History, 43(1), 13-38.

World Bank (2019) 